\title{
Effects of growth regulators on fruit set and June drop of pears and apples ${ }^{1}$
}

\author{
A. Varga \\ Department of Horticulture (TNO-research), Agricultural University, Wageningen, the \\ Netherlands
}

Received 7 January 1969

\section{Summary}

To increase yields of pear and apple trees the growth regulators kinetin, gibberellin $\left(A_{3}\right.$ and a mixture of $A_{4}$ and $\mathbf{A}_{7}$ ), N-dimethylaminosuccinamic acid (Alar) and (2chloroethyl)trimethylammonium chloride (CCC) were applied by spraying on blossoms or fruitlets and by injection into the trunk. Kinetin and particularly gibberellins were effective in stimulating fruit set in pears. Doyenné du Comice pear set more fruits with a mixture of gibberellin $\mathrm{A}_{4}$ and $\mathrm{A}_{7}$ than with gibberellin $\mathrm{A}_{3}$.

Although the majority of stimulated fruits abscised during the June drop period, the crop was markedly increased. The growth retardants Alar and CCC were inactive in increasing fruit set, but prevented excessive drop of fruits when applied after a gibberellin application.

\section{Introduction}

Some auxins and gibberellin $A_{3}$ increase fruit set of pome fruits as reported for pears by Gorter and Visser (1958), Luckwill (1959), Modlibowska (1960) and Varga (1968), and for apples by Dennis and Edgerton (1962) and Varga (1966). The practical problems have not been solved, however. In many cases fruit set is satisfactory, but frequently the fruitlets are shed.

As there are indications (Varga, 1966) that $A_{3}$ may not be the most active of the gibberellins, a mixture of $\mathbf{A}_{\mathbf{4}}$ and $\mathbf{A}_{\mathbf{7}}$ was applied to induce fruit set. Kinetin was included because Pierik (personal communication) found that kinetin promoted the growth of fruits in vitro.

Fruits pass through a critical period in their development between the 5th and 9th week from flowering. Before this period the fruits grow vigorously, and so do leaves and shoots. The developing leaves compete with the fruits and the fruits compete with one another. The result is that many fruits drop.

Alar and $\mathrm{CCC}$ were applied to eliminate excessive fruit drop by growth retardation of the leaves and the shoots. 


\section{Materials and methods}

Growth regulators were applied to 4 years old trees of the pear varieties Beurré Hardy and Doyenné du Comice, and the apple varieties Cox's Orange Pippin and Golden Delicious, grown in 50-litre containers. The trees were placed in an unheated glasshouse where they flowered. The minimum temperature was $18^{\circ} \mathrm{C}$.

Each of the trees had at least 50 spurs. The flower buds on the one-year shoots were not counted, nor were they used in the experiments. The top flowers of the clusters and the other flowers, which were not used, were removed before the treatments.

In the fruit set experiments each treatment included 120 clusters, spread over four trees. The number of blossoms was reduced to 3 per cluster before the treatments. The flowers were not covered, as in the glasshouse no insects were seen at any time. The experiments included treatments with and without pollination by hand.

For the experiments aimed at reducing June drop the fruits from pollinated flowers were used. The treatments were carried out on the 21 st day after pollination by spraying the fruitlets. In addition to sprays, aqueous solutions with $14 \mathrm{mg}$ of active substance per tree were injected into the trunk.

The effect of gibberellin $\mathbf{A}_{3}$ and Alar on competitive fruit growth was studied with Beurré Hardy pears. Per treatment 100 clusters were used with 3 flowers and 100 with 5 flowers, distributed over 20 trees. The flowers were pollinated by hand with Doyenné du Comice pollen.

Aqueous solutions were used of the chemicals: 6-furfurylaminopurine (Kinetin, K) at $25 \mathrm{ppm}$, gibberellin $\mathrm{A}_{3}\left(\mathrm{GA}_{3}\right)$ at $25 \mathrm{ppm}$, a mixture of $28 \%$ gibberellin $\mathrm{A}_{4}$ and $72 \%$ gibberellin $\mathrm{A}_{7}\left(\mathrm{GA}_{4}+7\right)$ at $25 \mathrm{ppm}$, N-dimethylaminosuccinamic acid (Alar) at $2500 \mathrm{ppm}$ and (2-chloroethyl)trimethylammonium chloride (CCC) at $2500 \mathrm{ppm}$.

Fruit set was considered positive when swelling of the young fruitlets was observed on the 32 nd day after flowering. The trees were taken out of doors on the 64th day from full flowering time.

\section{Experimental results}

\section{Fruit set}

The effects of the growth regulators on fruit set, recorded on the $32 \mathrm{nd}$ day after treatment, are presented in Table 1.

Hand pollination has a marked effect. The application of $\mathrm{K}$ has a positive influence on the fruit set both with and without pollination. The effect of $K$ is stronger in pears than in apples. The effect of $\mathrm{GA}_{3}$ on pears, already wellknown, is very clear here and the high fruit set without pollination is particularly striking. After a $\mathrm{GA}_{4}+$; treatment the fruit set of Doyenné du Comice is very high, even higher without than with hand pollination.

Gibberellins stimulated seed abortion. After a $\mathrm{GA}_{3}$ treatment, there was $26 \%$ seed abortion and after a treatment of $\mathrm{GA}_{4}+742 \%$ abortion in the harvested fruits of the pollinated flowers. In the other pollinated varieties no seed abortion was observed. A marked stimulating effect of gibberellins on the fruit set of Golden Delicious was found.

The retardants Alar and $\mathrm{CCC}$ did not increase fruit set. Alar reduced the fruit set of pollinated Doyenné du Comice flowers. 
Table 1 Effects of growth regulators on fruit set of unpollinated $(-p)$ and pollinated $(+p)$ blossoms as percentage of treated flowers. Treatments were carried out at full flowering time.

Variety

(ariery

Beurré Hardy

Doyenné du Comice

Cox's Orange Pippin

Golden Delicious

\begin{tabular}{llllll}
\multicolumn{9}{c}{ Treatments } \\
\hline control & $K$ & $G A_{3}$ & $G A_{4}+7$ & Alar & CCC
\end{tabular}

$\begin{array}{rrrrrrr}-\mathrm{p} & 4 & 11 & 53 & - & 0 & 0 \\ +\mathrm{p} & 29 & 48 & 81 & - & 26 & 39 \\ -\mathrm{p} & 0 & 8 & 64 & 87 & 1 & 3 \\ +\mathrm{p} & 49 & 60 & 58 & 76 & 21 & 37 \\ -\mathrm{p} & 6 & 21 & - & 30 & 2 & 0 \\ +\mathrm{p} & 47 & 50 & - & 69 & 39 & 42 \\ -\mathrm{p} & 0 & 7 & 15 & 23 & 1 & 0 \\ +\mathrm{p} & 26 & 24 & 28 & 32 & 18 & 27\end{array}$

\section{June drop}

The results of the treatments are presented in Table 2. The data are expressed in percentage of fruit drop during the period from the treatment (21st day after full flowering) to the 64th day after flowering.

A very high percentage of the Doyenné du Comice fruits dropped. A kinetin treatment reduced fruit drop of pears, but not of apples. $\mathrm{GA}_{3}$ had no effect on the $a b-$ scission of Beurré Hardy fruits, but reduced the June drop in Doyenné du Comice. $\mathrm{GA}_{3}$ stimulated the June drop of Cox's Orange Pippin and Golden Delicious. In pears, the effect of $\mathrm{GA}_{4}+7$ was the same as that of $\mathrm{GA}_{3}$, but in apples $\mathrm{GA}_{4}+7$ had no effect. Both Alar and CCC strongly reduced the percentage of fruit drop, in pears as well as in apples. June drop was eliminated almost completely when Alar and $\mathrm{CCC}$ were injected into the trunk. GA, when applied together with Alar, did not neutralize the effect of this compound.

Table 2 Effects of growth regulators on fruit drop as percentage of treated fruitlets. The treatments were carried out at the 21 st day after pollination by spraying the fruitlets or (between brackets) by injection in the trunk.

\begin{tabular}{lccccccc}
\hline Variety & \multicolumn{8}{c}{ Treatments } \\
\cline { 2 - 7 } & control & $K$ & $G A_{3}$ & GA +7 & Alar & CCC & GA + Alar \\
Beurré Hardy & 50 & 31 & 52 & 61 & 17 & 38 & $(26)$ \\
Doyenné du Comice & 94 & 41 & 68 & 50 & 30 & 73 & $-(13)$ \\
Cox's Orange Pippin & 21 & 26 & 57 & 25 & $11(9)$ & $18(3)$ & $(13)$ \\
Golden Delicious & 30 & 33 & 41 & 36 & $14(1)$ & $21(5)$ & $(16)$ \\
\hline
\end{tabular}

\section{Fruit set to harvest}

The total number of harvested fruits from 100 clusters is shown in Table 3.

If all the flowers form fruits, 300 and 500 fruits may be harvested from the 100 clusters. Although in the clusters with 3 flowers the percentage of fruit set is higher than in clusters with 5 flowers, the total number of set fruits is higher in the latter. From clusters with 5 flowers almost twice as many fruits were harvested as from 
Table 3 Influence of $G A_{3}$ and Alar on the total number of set and harvested fruits of Beurré Hardy pears. Per treatment 100 clusters, each with 3 or 5 flowers, were used. $G A_{3}$ was applied at full flowering time; Alar three weeks later.

\begin{tabular}{lcccc}
\hline Treatments & \multicolumn{2}{c}{3 flowers per cluster } & \multicolumn{2}{c}{5 flowers per cluster } \\
\cline { 3 - 4 } & fruit set & harvest & fruit set & harvest \\
untreated & & & & \\
GA $_{3}$ & 243 & 41 & 110 & 77 \\
Alar & 73 & 142 & 422 & 203 \\
GA $_{3}+$ Alar & 247 & 70 & 168 & 141 \\
& & 191 & 399 & 275 \\
\hline
\end{tabular}

clusters with 3 flowers, which means that in both cases the percentage of flowers which gave a fruit was about $15 \%$.

A treatment with $\mathrm{GA}_{3}$ strongly increased fruit set. This high number of fruits could not be kept on the tree until the harvest, certainly not in the treatment of 5 flowers per cluster. Even so, the crop after $\mathrm{GA}_{3}$ treatment was three times as high as that of the untreated trees. An application of Alar almost completely eliminated the drop

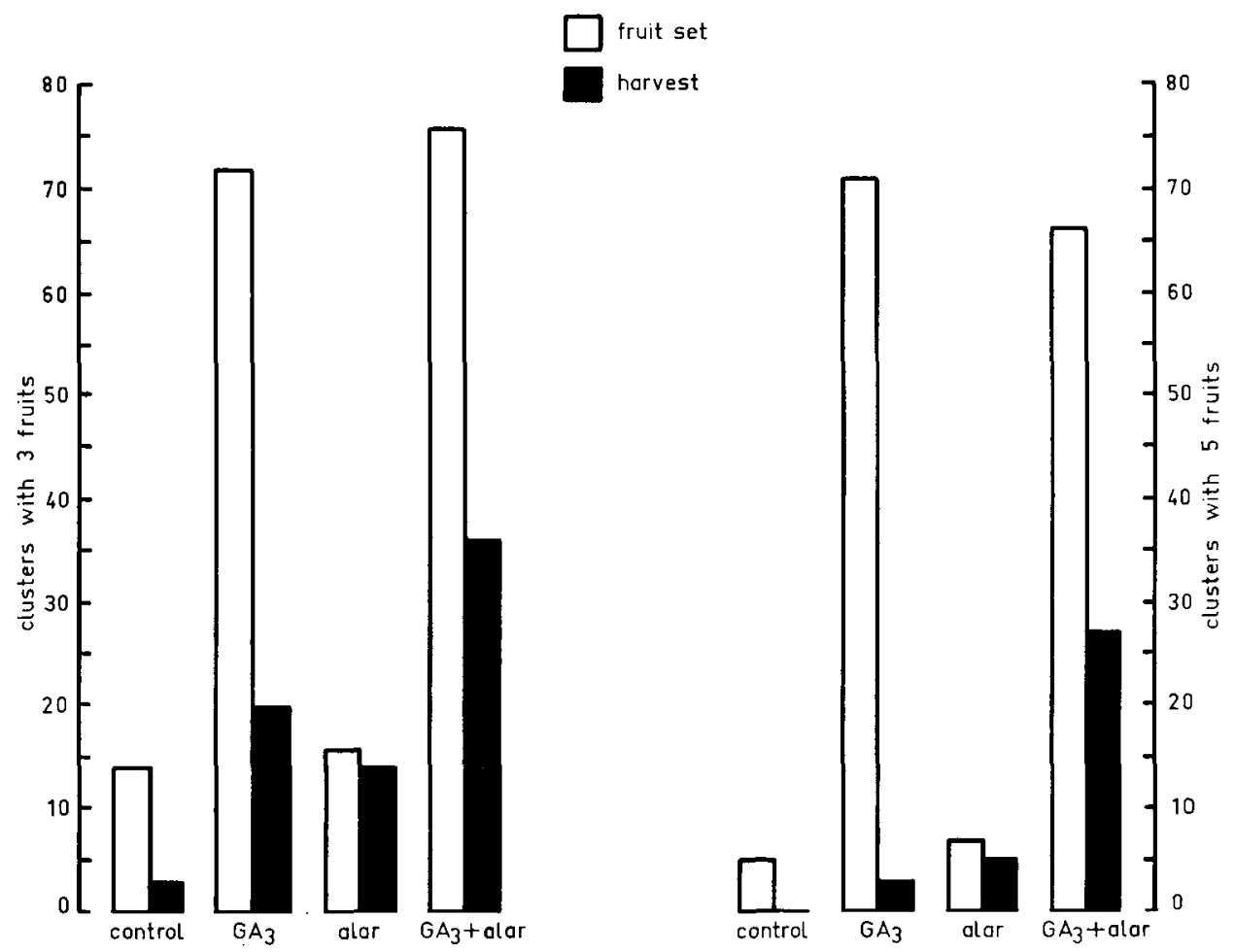

Fig. 1 Influence of $G A_{3}$ and Alar on the number of clusters pruned to 3 flowers (left) or 5 flowers (right), at the time of fruit set and at harvest. 
of the fruits in the clusters with 3 flowers. Even in the clusters with 5 flowers fruit drop was strongly reduced.

In the combined treatment, both effects occurred simultaneously. GA $A_{3}$ markedly increased fruit set and many fruits were retained by Alar until the final harvest.

The effect of $\mathrm{GA}_{3}$ and Alar is even more clear when only those clusters are taken into account which kept 3 or 5 fruits from fruit set to harvest. These data are presented in Fig. 1.

Only 3 clusters have given a harvest of 3 fruits per cluster and not one cluster has given 5 fruits without any treatment. After a $\mathrm{GA}_{3}$ treatment 20 clusters beared 3 fruits and only 3 clusters beared 5 fruits. After an Alar treatment, the number of clusters with 3 and 5 fruits was not markedly decreased. The strongest effect was obtained after the combined use of both types of regulators. At harvest time 36 clusters bore 3 fruits and 27 clusters 5 fruits. This is a very marked improvement of the crop in comparison with the control and $\mathrm{GA}_{3}$ or Alar alone.

\section{Discussion and conclusions}

Pollination stimulated fruit set, but so did kinetin and the gibberellins. It seems that in the Doyenné du Comice pear (Table 1) pollination can be adverse for fruit set if combined with a gibberellin treatment. Alar did not increase, and sometimes even decreased, fruit set. That it nevertheless had a positive effect on yield was caused by the inhibition of June drop.

Most of the set fruits were lost in June. Many more fruits dropped from trees treated with gibberellin than from the untreated trees. Nevertheless, the former yielded more fruits than the latter. It is of further interest that in Beurre Hardy pears the 27 clusters with 5 fruits each have given a higher yield in the most succesful combination of $\mathrm{GA}_{3}+$ Alar than the 36 clusters with 3 fruits each. The percentage of these clusters in the total crop was lower $(49 \%)$ in the case of 5 fruits per cluster than in the case of 3 fruits $(56 \%)$. This suggests that a stronger competition occurs when there are 5 fruits in a cluster than when there are only three.

\section{Acknowledgments}

Sincere thanks are due to $\mathrm{Mr} \mathrm{O}$. Borsboom for carrying out the experiments.

\section{References}

Dennis, F. G. and Edgerton, L. J., 1962. Induction of parthenocarpy in the apple with gibberellin and the effects of supplementary auxin application. Proc. Am. Soc. hort. Sci. 80: 58-63.

Gorter, C. J. and Visser, T., 1958. Parthenocarpy of pears and apples. J. hort. Sci. 33: $217-227$.

Luckwill, L. C., 1959. The effect of gibberellic acid on fruit set in apples and pears. Rep. agric. hort. Res. Stn Univ. Bristol: 59-64.

Modlibowska, I., 1960. Stimulation of fruit development in frost damaged pears. Rep. E. Malling Res. Stn: 46-48.

Varga, A., 1966. The specificities of apple cultivars and of gibberellins in the induction of parthenocarpic fruits. Proc. K. ned. Akad. Wet. C 69: 641-644.

Varga, A., 1968. The use of gibberellins on pears and apples. Meded. LandbHogesch. OpzoekStns Gent 33: 1321-1327. 